$\mathrm{PhD}$ in Philology, Associate Professor, Head of the Department of Ukrainian Studies and Humanitarian Training, Poltava State Medical University, 36011, Poltava, 23 Shevchenko Street, tetyana.57@ukr.net

Maryna Zhovnir ORCID.ORG/0000-0001-8498-9802

$\mathrm{PhD}$ in Philology, Lecture of the Department of Ukrainian Studies and Humanitarian Training, Poltava State Medical University, 36011, Poltava, 23 Shevchenko Street, m.zhownir@gmail.com

Natalia Grinko ORCID.ORG/ 0000-0003-3527-3546

$\mathrm{PhD}$ in Medical Psychology, Lecture of the Department of Nervous Diseases, Psychiatry and Medical Psychology, Bukovinian State Medical University, 58002, Ukraine, Chernivtsi, Teatralnaya Square, 2, grinko.natalia@bsmu.edu.ua

\title{
TEACHING UKRAINIAN AS A FOREIGN LANGUAGE BY USING MIND MAPPING TECHNIQUE
}

The article is devoted to the problem of successful implementation of different cuttingedge techniques in teaching in the context of the current significant modifications and profound transformations of the educational system in Ukraine. This work focuses on forming a foreign medical student linguistic personality, in particular, its grammar, speech, communication as well as socio-cultural competencies, including by utilizing Advanced Information and Communication technology tools. This research focuses on the introduction of Advanced Information and Communication Technologies into the Ukrainian educational process. It was pointed out, that the effective teaching methodology could be based on the newest methods and techniques. The advantage of pedagogical innovation in 
comparison with traditional methods of presenting educational information was pointed out. The researchers have interpreted the term Mind map. They have also presented and analyzed its important features, common ways of implementation into the current teaching process.

Keywords. innovative technologies, Mind mapping, foreign student, Ukrainian as a foreign language, medical university.

(C) Leshchenko Tetyana, Zhovnir Maryna, Grinko Natalia, 2021

https://doi.org/10.28925/2312-5829.2021.2.8

Introduction. Ukrainian for non-native speakers has become an important requirement in the world of current education. It gives access to necessary information and modern technologies. It is commonly known that in contrast to English, Arabic, French, German and Mandarin, Ukrainian is not one of the five International languages recognized by the United Nations, and it's not spoken worldwide. However, Ukrainian must be obligatorily learned by foreign students who enter Ukrainian higher educational establishments to get a diploma and to receive the appropriate training in particular occupations - including Medicine and Dentistry. Nowadays these specialities are in the highest demand among youth from Morocco, Syria, Jordan, Iran, Iraq, Lebanon, Palestine, Ghana, Nigeria, Pakistan, India, etc.

Education plays an important role in modern foreign youths' lives, as well as in Ukrainian young girls' and boys' future employments. To become a well-qualified specialist and get a good place for work they all need to have an appropriate education. It's a great value, («a complex of vital material and spiritual, non-material concepts that outline the basic behavioural dominant of a person» (Leshchenko, 2018, p. 168) for them. So, foreign students are eager to follow special programs and acquire qualifications. In this response, Ukrainian higher educational establishments expand training opportunities for all foreign students. Hence the number of students mastering the medical occupations in our country is constantly growing.

Concerning accessing ample studying opportunities and resources foreign students also have been able to learn something new about Ukraine, its history, ancient and presentday traditions, religion and cultural peculiarities, that characterize the sociocultural fabric 
of our country. For most of Ukraine and the common standard of living of its citizens was initially unclear. They were puzzled because it didn't seem like much in their country. But on the other hand, they did everything they could to survive under the new conditions and to understand the rules of life within Ukrainian society.

It's commonly known, that different national situations are reflecting different cultures, histories and traditions. Language learning is an important aid in the understanding of the characteristics of each country. So, «Foreign students seek to speak Ukrainian to study the educational material included in curricular and to adjust the realities of Ukrainian way of life» (Leshchenko T., 2020, p. 126).

In this response, the function of language tutors is to assist foreign students with their language education and help strengthen the cultural specificities of the Ukrainian people. In our opinion, language teachers must obligatorily use remarkable achievements in the field of education. It's difficult to disagree with T. Leshchenko, who notes that «Accessibility and availability of learning opportunities can be effectively increased and streamlined. Thus, teachers must be creative and do their best to increase students motivation and engage them in learning Ukrainian» (Leshchenko T., 2020, p. 22).

Advanced technology has become both a fundamental and significant part of our modern society and present-day educational space. It is near impossible to imagine current life without being connected to the online world. Anyway, we somehow involved with using information and communication technology tools. The above-mentioned tools and techniques have become an essential aspect of our world in various aspects and spheres, including education. So, nowadays, «Pedagogical innovations are focused on searching new and adequate mechanism to actualize special potential» (Aslamova M., 2019, p. 7).

As it was also indicated by the researcher mentioned above, «With the coming of the information age in our modern society, globalization and total informatization of all shares, in the particular educational sector, a lot of efforts for successful implementation of different cutting-edge techniques in teaching have been put» (Leshchenko T., 2020, p. 125). The cutting-edge didactic material, modern educational tools and equipment should be utilized to increase the efficiency of teaching support the education process and vitalize the subject by enriching the process to improve the learning algorithm. There are huge numbers of 
effective techniques and methods available to be utilized in language courses. If a different method is used in the study, this should be explained in detail.

The aim of the research. In this research, we concentrate on the algorithm of modernizing the teaching of the discipline «Ukrainian as a Foreign Language». This research aims to determine the effect of the Mind mapping technique used in Ukrainian language studying on students' achievements and their attitudes towards the mentioned advanced technique.

Given the motivation for this research, the aims and the objectives, we accentuated the following research questions: 1) What is the main reason for using the most advanced Information and Communication Technologies (ICT) for educational purposes?; 2) What are the main challenges of utilizing the Mind maps technique?; 4) Can the implementation of different cutting-edge techniques in teaching be regarded favourably?; 5) What kinds of benefits will we have after this?

As for us, it's better to come straight to the point. Thus, the use of information and communication technologies in the educational process, particularly in language learning is an urgent challenge of the modern educational system. We are certainly not implying only the national educational paradigm. If we summarize all the information stated above, understandably and effectively utilizing ICT is essential worldwide. ICT has been recognized as the important tool to enchase learning and teaching all around the world.

The basic problems of implementation of the ICT in the educational process were investigated by Ukrainian and foreign researchers (G. Ahluwalia, O. Betsko, O. Bihych, M. Byrka, G. Voronina, A. Carvalho, G. Dudeney, S. Danilyuk, M. Chernii, M. Zhovnir, T. Leshchenko, T. Pozdnyakova, N. Tereshchenko, V. Vitiuk, etc.). These researches have already explained the essence of ICT, have defined the term and have successfully analyzed its basic peculiarities, and described main the specific ways of practical implementation ICT to the educational process.

Mind maps were successfully implemented in the educational process all over the world. Such creative experiments helped students to find a more balanced approach to studying, in particular to the encoding of the necessary information. These alternative recording techniques tend to intensify associative thinking. At the same time, this thought 
process allows seeing important factors missed with traditional analysis or discussion. The maps help to reveal useful information. It heightens motivation and inspires critical thinking and visual learning, as well as promotes innovation and creativity.

Mind maps are required for different purposes, such as creating, visualization, structuring and classification of some views, ideas or facts. These maps can be used as a way of learning as well as teaching. They might be utilized to organize different process, events, solutions and decisions. Mind maps help to make the process of translation simpler. Some tutors prefer to use these visualization tools as the basis for scientific articles and researches.

A lot of scientists emphasized, that the mind-map picture gives the presenters the opportunities of promoting a new awareness, various kinds of discoveries, and a deeper reflection about their works. It should be noted, that they have already explained the essence of Mind mapping, have defined the term and have successfully analyzed its basic peculiarities. In addition to the above-mentioned, scientists have already described in detail the specific ways of practical implementation of ICT, particularly the diversity of Mind mapping tools to the educational process.

Taking into account the background, results, evident progress and obvious benefits of these researches, we should note that there is still a piece of information, describing using Mind maps in teaching Ukrainian to foreign medical students.

Research methods. The research was performed within the anthropocentric scientific paradigm. Basic - general linguistic method of scientific description. The paper appeals to the generalization, systematization, classification, interpretation of linguistic scientific fact. The descriptive-analytical method was used to analyze and systematize the features of ICT implementation in the educational process; comparison method - to compare innovative and traditional educational methods and techniques.

The results and discussion. Mind mapping is a technique promoted by T. Buzan (Buzan T., 2004). He is not only the founder of Mind mapping. Many years ago T. Buzan has also created and explained in detail the term mental literacy. He had collected all his ideas and thoughts in this regard and has introduced the readers to his books. 
According to T. Buzan, «A mind mapping is the ultimate organizational thinking tools» (Buzan T., 2004, p. 14). He compared a Mind map to a city map for convenience of understanding. He said that the centre of a city is like the centre of a Mind map. The main road in the city is equal to the main thought in the thinking process, and the secondary road represents the secondary thought, and so on. With the Mind Map, you will know where you are going and where you have been (Buzan T., 2004, p. 32).

To quote J. W. Budd, «A mind map is an outline in which the major categories radiate from a central image and lesser categories are portrayed as branches of larger branches» (Budd J. W. , 2010, p. 36). Mind mapping software can be utilized to deliver a distinctive visual display of how learners generate, categorize, arrange, associate, and synthesize information to construct on their existing knowledge (Pozdnyakova T., 2018, p. 8). «A typical mind mapis a visual representation of a central main topic from which nodes, subnodes, groupings, branches or areas are classified with the goal of representing semantic information» (Kotcherlakota S., 2013, p. 253).

Meantime, we consider that using Mind maps the list of terms, definitions, word, word combinations and important phrases can be visualized. The use of this technique fosters remembering and learning, developing the imaginations and creativeness of students. In other words, Mind maps are graphical tools for creating, organizing, representing, and sharing knowledge. Mind mapping contributes students to conduct a constructive exercise of their thought processes and also teaches them to think reflectively about their language practice.

T. Buzan has proposed, in his word, to consider Mind mapping as an alternative and the easiest way to put information into the students' brain. From his point of view, it's a creative and effective means of note-taking that literary «maps out» the student thoughts. Based on the explanation above, the researcher concludes that Mind mapping is the easiest way to represents the student thinking process. Many great benefits can be gained from using Mind mapping technique: «Mind-mapping cannot only help us develop a differential diagnosis but also define a management plan and assign tasks and responsibilities for a team. Mind-mapping is also an excellent tool to organize a talk or written product such as a lecture or case summary» (Jonathan S., 2019, p. 5). 
In our opinion, Mind maps are also useful for solving communicative tasks, various troubles with remembering new lexical or grammar material, problems with systematization, collating, and codifying or sharing language information. It successfully provides brainstorming mechanisms to promote ideas, learning new vocabulary, rapid acquisition of Ukrainian with a focus on memorize-related language skills.

Our methodical experience reveals that the use of the Mind mapping technique in Ukrainian teaching provides an active role for foreign students. The most significant results of this study have shown that utilize of Mind mapping technique simultaneously can systematically make important educational information more organized and readable.

They make an evaluable visual representation that portrays the associations among facts, terms, concepts, and ideas within a learning task, which are enclosed in circles, triangles or ovals. The geometric shapes, different lines and figures utilized in the maps may facilitate students to effective visualize patterns and discover interrelationships between concepts, ideas, words or grammar points. Sometimes students even cannot obtain some difficult tasks/exercises unless the current Mind map is complete.

In addition, if students get such exciting tasks, they undoubtedly will try to accomplish them. They can't duplicate someone's ideas or thoughts. They probably will seek to outdo their classmates. It's hard to disagree that Mind mapping is a specific system that uses brain recourses to open all the internal mind potency and capacity. And, importantly, it promotes the effectiveness and great pleasure from learning new material, particularly information from different areas of the Ukrainian language. It's extremely important for learning languages. For some students, Ukrainian becomes an obstacle not because it is considered the most difficult skill to master. Students show a reluctance to learn Ukrainian and to use it in their everyday communication. Language tutors face many challenges at the moment they are starting working with a particular foreign group.

The goal of Ukrainian teaching in Ukrainian medical higher educational establishments is to better equip the students with the ability to develop: 1) oral and written communicative competence; 2) the understanding of the importance of Ukrainian roles played in day-to-day communication; 3) the awareness about the interrelationship of language and culture. 
So, there is always a need for appropriate techniques to be adapted to teach different language skills. About Mind mapping, teachers should create a favourable environment for understanding the necessity, mandatory as well as simplicity of learning Ukrainian.

T. Buzan mentions few steps to create a Mind mapping as follows: 1) identifying the goals of making mind mapping clearly, which is focused on the precise topic from phenomenon around; 2) turning the first sheet of paper sideways in landscape-style and starting to create mind mapping in the centre of the page; 3 ) drawing an image or picture in the centre of the blank sheet of paper to represent the goal, which is the topic; 4) using colour from the outset to emphasis structure, texture, creativity to stimulate visual flow and reinforce the image in students' mind; 5) drawing a series of thick lines, radiating out from the centre of the image. Mind Maps are based on associations and connections; 6) curving the lines because they are more interesting to the eyes and more memorable to the brain than the straight ones; 7) putting a keyword on each branch that associates the topic (Buzan T., 2004, p. 29).

We reiterate that we have a lot of foreign students mastering the medical occupations in Ukraine. Mind mapping technique is used by them for quick and effective remembering terms, words and active topical phrases. It helps students to memorize active vocabulary and expressions on certain subjects, particularly Ukrainian. These diagrams organize facts and ideas around one, central subject. It combines words, pictures and lots of colours to summarize complex information visually.

Let's look at a couple of examples. Students were asked to create their Mind map on a certain topic. We would like to suggest few Mind maps (Figure 1,2). It's important, that all terms, facts and ideas (topic «Weather. Weather phenomena», «Calendar» (the $1^{\text {st }}$ year students) of all topics can be fed into the concrete Mind map individually.

For creating Mind Maps the following computer programs can be utilized: Google, Mind Jet, Mindmeist, Mind Manager, Mindomo, Free Mind, Concept Draw, Bubbl.us, Spiderscribe, etc. They have used the $2^{\text {nd }}$ and the $5^{\text {th }}$ ones not just because they are really easy to use. These computer programs can be used for free. Meantime, the diversity of extra options is available at an additional cost. 


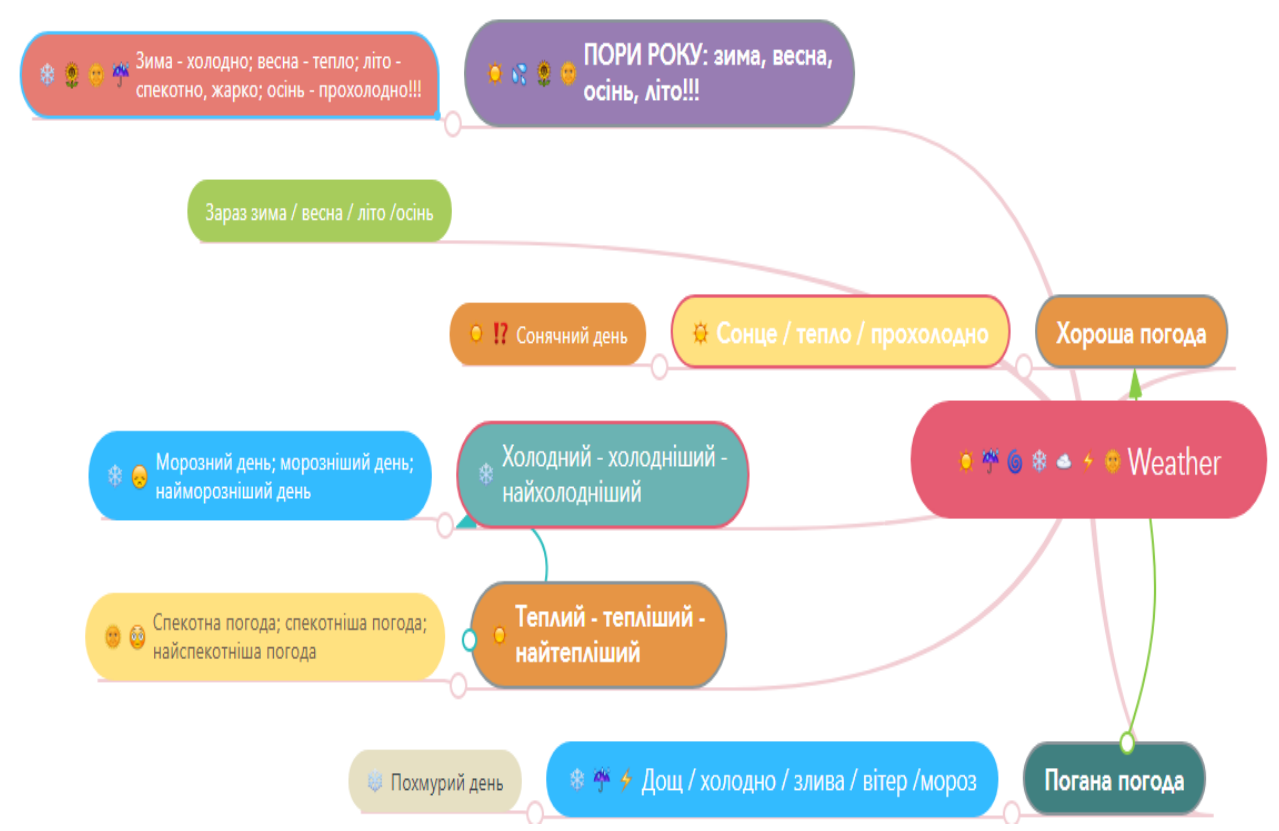

Figure 1. The Mind map «Weather. Weather phenomena» (it was done using Mindmeist).

As can be seen from the above-given map, when you make your map, you are already analyzing and categorizing information, systematizing words, terms, creating the most important informational points. Mind maps help all learners to not only organize their ideas in a hierarchical structure but also make them able to produce linked and better-connected concepts. This example shows that main grammar items can be easily combined with basic lexical material.

The following example illustrates that using one or a few keywords per line helps students to determine every part of the topic. New words and the relationship between them are clarified. So, students can easily remember them.

The combination of words and pictures make it easier to memorize than just words alone. Even if students' pictures aren't perfect, the fact that they use images and different colours can make studying more fun. Mind mapping is very personal note-taking and reviewing. These examples demonstrate a creative approach to making design. Meanwhile, it needs much practise to master this technique. 


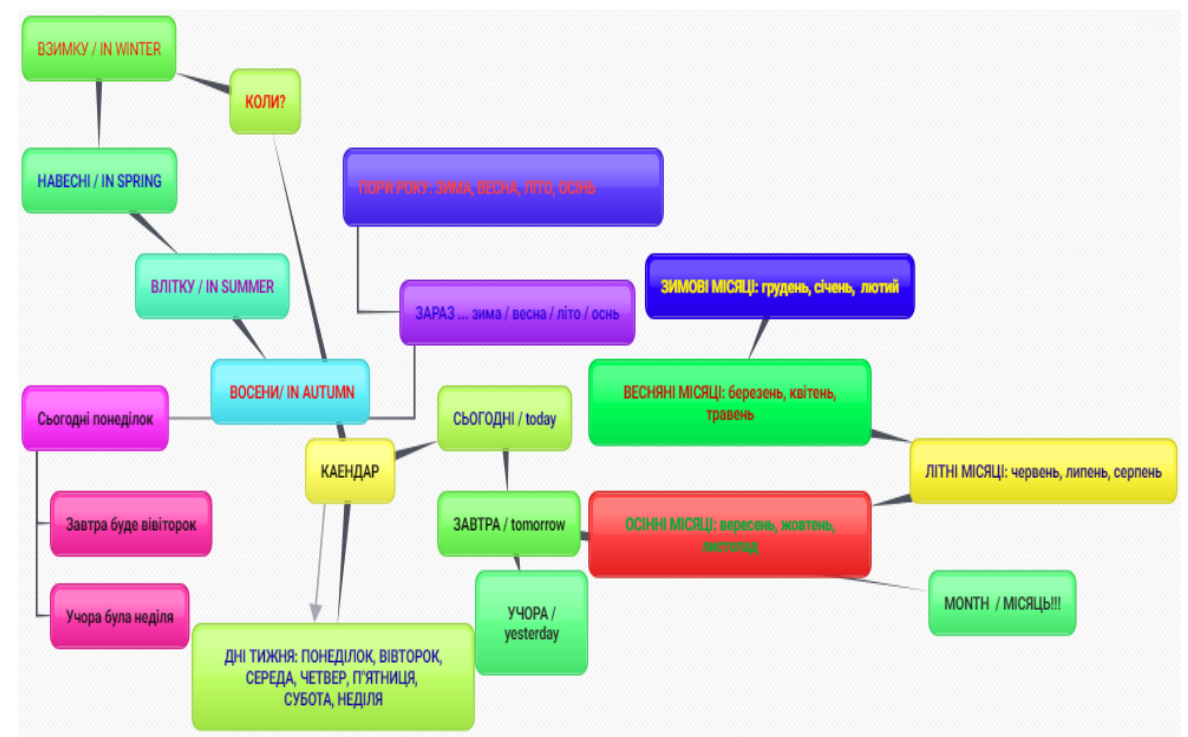

Figure 2. The Mind map «Calendar» (it was done using Mind Jet)

Making Mind maps doesn't waste a lot of study time. So, you can get finished the Mind map quickly enough. As for us, it can look something like this. It seems, however, there can be more options within the framework outlined by the teacher.

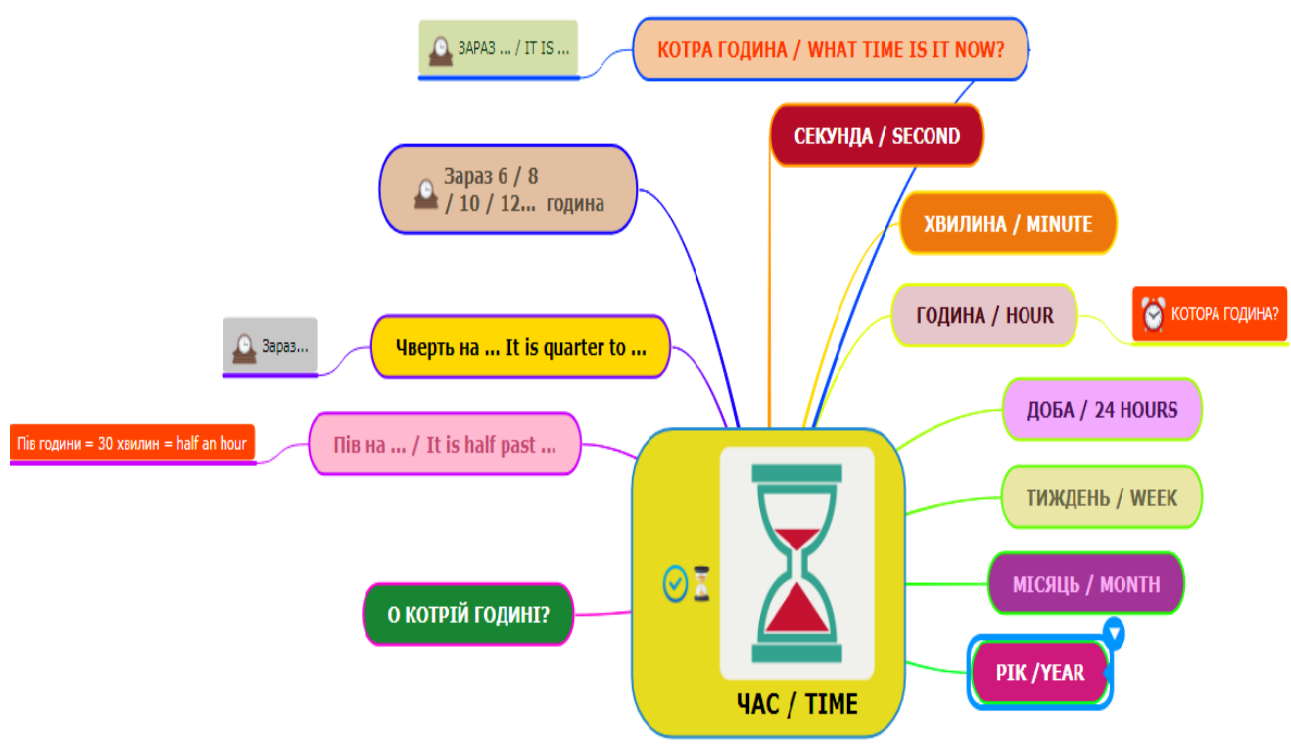

Figure 3. The Mind map «Time» (it was done using Mindomo)

It's noteworthy that the above-mentioned Mind map is just one of the variety of possibilities we can have. All the terms and active topical vocabulary of this topic/tasks can be fed into the concrete Mind map individually. Consequently, these computer programs give access to the common drafting of the Mind maps, when you are trying to create them in real-time. Furthermore, some programs make the individual access to the map or its part feasible. 
Conclusions. In summing up all thoughts and ideas, it's hard to imagine modern life without being connected to the online world somehow using ICT. We should point out that one of the most important tasks of the educational system today is to introduce and continue to make steady progress on the implementation educational technologies that could facilitate the formation of a creative and active personality, able to meet the challenges and to achieve the desired goals.

There are numbers of techniques and methods available to be utilized in language courses. Different pertinent visual learning application software is among them. Mind mapping software is among these applications that have been recognized broadly to be a very effective ICT tool in education for learners of all ages and in all subject areas, including learning Ukrainian.

Integrating Mind maps into education and frequent utilizing this technique as a teaching or learning tool provides various benefits for teachers and students alike. So, we believe, that Mind maps and their related tools are also relevant and useful ingredients for success in language education. It's a creative way to show how learners generate, categorize, arrange, associate, and synthesize educational information to construct on their existing knowledge.

In our view, the Mind Map should play an important role in teaching practices. Promoting multiple activities and tasks for creating Mind maps are preferable. These activities make students motivated to produce their map structure and phrases, and as a result, they can quickly and effective remembering terms, words and active topical phrases. From our point of view making Mind maps can foster a deeper understanding of contents, words, terms, etc. So, the Mind mapping technique can be successfully implemented in the language classroom, providing creative and available tool both for students and teachers. In future researches, we will focus on this item in greater depth.

\section{References}

1. Jonathan, S. (2019). An Introduction to Medical Decision Making. Springer International Publishing (eng).

2. Leschenko, T. (2018). Zdorov'ya vs. hvoroba v konteksti slovesnoyi reprezentaciyi cinnisnoyi kartini svitu suchasnogo likarya [Health vs. illness in the context of verbal 
representation of the value picture of the world of the modern physician]. Psycholinguistics, 24 (2), p. 163-180, https://doi.org/10.31470/2309-1797-2018-24-2-163-180 (ukr).

3. Leshchenko, T., \& Zhovnir, M. (2020). Vikoristannya elektronnogo servisu Kahoot pid chas vivchennya predmeta «Ukraïns'ka mova yak inozemna» $u$ vishchomu medichnomu zakladi osviti [The use of Kahoot to study Ukrainian Language as Foreign in medical higher educational institution]. Modern medical education: methodology, theory, practice: materials All-Ukrainian. scientific-scientific conf. with international participation (Poltava, March 19, 2020). Poltava, 2020. p. 124127 (ukr).

4. Leshchenko, T., \& Zhovnir, M. (2020). Mind mapping technique in Ukrainian as a foreign language teaching».Tendenze attuali della moderna ricerca scientifica: der Sammlung wissenschaftlicher Arbeiten $\left\langle\Lambda^{\prime} \mathrm{O} Г О \Sigma » \mathrm{zu}\right.$ den Materialien der internationalen wissenschaftlich-praktischen Konferenz (B. 2), 5. Juni, 2020. Stuttgart, Deutschland: Europäische Wissenschafts plattform. p. 20-23, 10.36074/05.06.2020.v2.05 (eng).

5. Aslamova, M., Zhovnir, M., Bondar, N. (2019), Internet-shchodenniki inozemnih studentiv yak element diskursu blogosferi [Internet journals of foreign students as an element of the discussion of the blogosphere]. Scientific notes of Taurida National V.I. Vernadsky University, series Philology. Social Communications. 2019. №4. p. 6-10, https://doi.org/ 10.32838/2663-6069/2019.4-1/02 (ukr).

6. Budd, J. W. (2010). Mind Maps As Classroom Exercises Articlein». The Journal of Economic Education. №35(1), p. 35-46, https://doi.org/ 10.3200/JECE.35.1.35-46 (eng).

7. Buzan, T. (2004). The Mind Mapbook: How to Use Radiant Thinking to Maximize Your Brain's Untapped Potential. New York, Pengiun Book (eng).

8. Pozdnyakova, T. (2018). Vizualizaciya ta strukturuvannya informaciyi za dopomogoyu mental'nih kart na urokah biologiyi [Visualization and structuring of information with the help of mental maps in biology lessons] (ukr).

9. Kotcherlakota, S. Zimmerman L., Berger A. M. (2013). Developing Scholarly Thinking Using Mind Maps in Graduate Nursing Education. Nurse Educator. №38 (6), pp. 252-255, https://doi.org/ 01.NNE.0000435264.15495.51 (eng).

\section{НАВЧАННЯ УКРАЇНСЬКОЇ МОВИ ЯК ІНОЗЕМНОЇ ЗА ДОПОМОГОЮ МЕНТАЛЬНИХ КАРТ}

Тетяна Лещенко, кандидат філологвчних наук, доцент, завідувачка кафедри українознавства та гуманітарної підготовки Полтавський державний медичний університет, вул. Шевченка, 23, 36011, м. Полтава, Україна, tetyana.57@ukr.net

Марина Жовнір, кандидат філологічних наук, викладач кафедри українознавства та гуманітарної підготовки, Полтавський державний медичний університет, 
вул. Шевченка, 23, 36011, м. Полтава, Україна, m.zhownir@gmail.com

Наталя Гринько, кандидат медичних наук, асистент кафедри нервових хвороб, психіатрії та медичної психології ім. С. М. Савенка, Буковинський державний медичний університет,

Театральна площа, 2, 58000, м. Чернівці, Україна, grinko.natalia@ bsmu.edu.ua

Статтю присвячено проблемі ефективного впровадження надсучасних освітніх технологій $і$ методів у навчальний процес в контексті суттєвих модифікаиій $і$ змін 6 галузі вітчизняної освіти. У розвідиі розглянуто ключові аспекти формування мовної особистості іноземного студента-медика, його мовної, мовленнєвої, комунікативної й соиіокультурної компетентностей иляхом раџіонального використання освітньої інноватики й актуального інформаційного й технічного забезпечення навчального прочесу. Авторами зауважено про важливість і своєчасність педагогічних новацій та осучаснених педагогічних методів $і$ методик для активізачії студентської активності, послідовності в навчанні, а також для розкриття ӥхнього внутрішнього потенціалу, саморозвитку, стимуляиії пошукової активності, систематизації навчальної діяльності ци упорядкування набутих раніше знань. Дослідниками зауважено про ефективність впровадження інформаційно-комунікаиійних новацій в освітній процес у закладах вищої освіти. Крім иьвого, у праці вказано на переваги педагогічної інноватики у порівнянні з традиційними методами подачі навчальної інформачії. Проінтерпретовано й систематизовано окремі теоретичні зауваги щзодо суті та специфіки використання ментальних карт під час вивчення украӥнської мови іноземними студентами. $У$ розвідиі також витлумачено термін інтелектуальна (ментальна) карта, наведено й проаналізовано узуальні особливості карт. Подано перелік комп'ютерних програм, які можна використовувати для створення індивідуальних ментальних карт. Обтрунтовано доиільність $i$ раціональність використання тематичних ментальних карт на заняттях із дисципліни «Українська мова як іноземна» в медичному виші. Подано й детально проаналізовано низку ментальних карт, які можна використовувати під час вивчення студентами-медиками навчального предмета «Украйнська мова як іноземна» (I курс, спеціальність «Медицина»).

Ключові слова: інновачійні технології, (інтелектуальна) ментальна карта, студент-іноземець, украйнська мова як іноземна, медичний вищий заклад освіти.

\section{ИЗУЧЕНИЕ УКРАИНСКОГО ЯЗЫКА КАК ИНОСТРАННОГО ПРИ ПОМОЩИ МЕНТАЛЬНЫХ КАРТ}

Татьяна Лещенко, кандидат филологических наук, доцент, заведующая кафедрой украиноведения и гуманитарной подготовки,

Полтавский государственный медицинский университет,

ул. Шевченка, 23, 36011, г. Полтава, Украина, tetyana.57@ukr.net

Марина Жовнир, кандидат филологических наук, 
преподаватель кафедры украиноведения и гуманитарной подготовки, Полтавский государственный медицинский университет, ул. Шевченка, 23, 36011, г. Полтава, Украина, m.zhownir@gmail.com

Наталья Гринько, кандидат медицинских наук, ассистент кафедры нервных болезней, психиатрии и медицинской психологии им. С. М. Савенка, Буковинский государственный медицинский университет, Театральная площадь, 2, 58000, г. Черновцы, Украина, grinko.natalia@bsmu.edu.ua

Статья посвящуена проблеме эффрективного и своевременного внедрения современных технологий в учебный процесс в контексте существенных модификаций и изменений в области отечественного образования. В статье рассмотрено ключевые аспекты формирования языковой личности иностранного студента-медика, в частности, его языковой, речевой, коммуникативной $u$ социокультурной компетенции путем рационального использования педагогической инноватики, а также актуального информационного и технического обеспечения учебного прочесса. Авторами указано на важность и своевременность педагогических инноваций, новых методов и методик для активизации студенческой активности и последовательности в обучении, а также для раскрытия внутреннего потенциала каждого студента, для его саморазвития, стимуляциии поисковой активности, систематизации учебной деятельности и знаний. Исследователи акцентируют внимание на небходимости и эффективности внедрения информационно-коммуникационных технологий в учебный процесс высшего медищинского заведения. Кроме этого, в работе указано на преимущества педагогической инноватики по сравнению с традиционныли методами подачи учебной информации. Интерпретировано и систематизировано отдельные теоретические аспекты и точки зрения относительно сути и специффики исследуемых педагогических технологий. B статье предложень компьютерные программы, которые можно использовать для создания индивидуальных интелектуальных (ментальних) карт. Авторами обоснованы целесообразность $u$ рациональность использования рассматриваемой технологии на занятиях украинского языка как иностранного в медицинском высшем учебном заведении. Представлены и подробно проанализированы несколько ментальных карт, которые можно использовать при изучении студентами-медиками учебной дисциплинь «Украинский язык как иностранный» (І курс, спецуиальность «Медицина»).

Ключевые слова: инновационные технологии, (интеллектуальная) ментальная карта, студент-иностранец, украинский язык как иностранный, медицинское высиее учебное заведение.

Стаття надійшла до редакиії 31.01.2021 p. Прийнято до друку 09.06.2021 